\title{
Efficacy of using Wheetly model In the learning of high jump competition
}

\section{${ }^{*}$ Dr. / Doaa Mohamed Mohy El Din}

\section{Introduction}

The present age is characterized by rapid scientific progress in all life fields generally and in the physical education field in particular, so some teaching techniques emerged which shared in developing the educational process in order to build generation being able to face the rapid changes of this age.

Modern educational theories appeared in the learning field, such as the constructive theory where Knowles (2005) refers to that the constructive learning strategy means that learning is an active positive process in which the student learns new ideas based on previous knowledge and educational experiences, and this education is by integrating the new knowledge with the old one found in the learner, then the previous concepts and ideas are amended to accommodate the new experiences $(20: 26)$.
Wheetly model is considered one of the models based on the constructive theory and Dalisel (2001) states that this model can be applied in all educational stages and it also considers the different abilities of the learners (15:21)

the

high

jump competition is one of the field competitions which is characterized by hard performance where the player needs to make use of all his body strength to exceed the beam $(5: 165)$

The researcher noticed a remarkable decrease in the level of the technical performance and the digital level of the students of the second grade in the physical education faculty, Tanta university in the high jump competition by the back method and this is shown by the marks of evaluation of the students over the first term and also the applied test of the first term, the researcher also

*Professor assistant in the field and racetrack competitions department, Physical education faculty, Tanta university Assiut Journal For Sport Science Arts 
noticed that there is a decrease in the knowledge acquisition level of the high jump competition by the back method and this is shown through the evaluation of the students in the theoretical lectures and also their marks in the oral and theoretical test of the first term, this may be referred to that the High Jump Competition by the back method is considered as one of the composite competitions including many technical stages and Both Abdel Rahman Zaher (2009) and Seki Salam (2014) agreed that the technical stages of the high jump competition is approaching, ascending . flying and landing. $(9: 188)(7: 126 ، 127)$

Also there is one style for teaching which is explaining and presenting by the teacher regardless of the principle of the differences in abilities and preparations among the students in which the role of the student is negative where she receives information and imitate the model, so this style does not satisfy the students needs of the skill and informational aspects, so we must use the teaching styles which make the student as the axis of the educational process (EP) regarding the individual differences among the students to develop the EP among which is Wheetly model for constructive learning which make the environment featured by thinking freedom and openness providing the students self trust through their ability to think and discuss in which the students work in small groups for solving the problem helping them to learn and amend thinking, also it may help students to acquire the social skills and also encouraging them to think by submitting tasks which motivate thinking. (14: 272, 273)

Also there are some studies which used Wheetly model such as the study of Pedrson and others (2001) (24), Fransworth, (2001)(22), Zumbach \& Reimann (2003) (27), Abdel Hamid ElYokobi (2010) (8), Needham, (2010) (23), Melody Mohamed (2015) (19) whose study result proved the positive effect of Wheetly model in education.

And in light of the above mentioned the researcher suggests using Wheetly model for learning the technical stages of the High Jump Competition by back method 
and also the theoretical aspects of the competition represented in (the technical stages competition rules - technical common mistakes and method of correcting them educational steps) of the research competition for the students of the second grade of the physical education faculty, in Tanta, and as the researcher knows, no researcher studies the use of Witly model in learning the High Jump Competition by back method hoping to improve the level of the technical performance and the digital level and the informational acquisition level of the research competition.

\section{Research aim:}

Recognizing the efficacy of Witly model for constructive learning in the level of the technical performance, the digital level and the informational acquisition level of the High Jump Competition by the back method of the students of the second grade in the faculty of physical education, in Tanta.

\section{Research propositions}

1) There are differences with statistical indication between the two averages of the pre and post measurements of the control group in the technical performance level, the digital level and the informational acquisition level of High Jump Competition by the back method for the post measurement.
2) There are differences with statistical indication between the two averages of the pre and post measurements of the experimental group in the technical performance level (TPL), the digital level (DL) and the informational acquisition level (IAL) of the High Jump Competition by the back method for the post measurement.

3) There are differences with statistical indication between the two averages of the two post measurements of the control and experimental groups in the TPL, DL and IAL, for High Jump Competition by the back method for the experimental group

\section{Research terminologies:}

Wheetly model: it was designed by Greson Wheetly formed from three stages which are the educational tasks, cooperative groups, contribution, (13: 850)

\section{Research methodology:}

The researcher used the experimental methodology with experimental design for the experimental and control groups by applying the pre and post measurements for the two groups.

Community and sample of the research:

The research sample was selected deliberatly whose 
number (75) students in the second grade in the physical education faculty, Tanta university for the academic year 2015/2016 from the total of the research whose number is (314) students, (3) students was excluded because of injury, and also (24) for making the exploring study, so the main research sample is (48) students by percentage of $15,28 \%$ and they were divided randomly to two equal groups: experimental (24) students and control group (24) students, table (1) shows the specification of the community and sample of the research.

Table (1)

Specification \& sample of research

\begin{tabular}{c|cc|cc|cc}
\hline \hline \multirow{2}{*}{ Ser } & \multicolumn{2}{|c|}{$\begin{array}{c}\text { Original } \\
\text { community } \\
\text { No. }\end{array}$} & \multicolumn{2}{c|}{ percent } & Main sample & \multicolumn{2}{c}{$\begin{array}{c}\text { Exploratory } \\
\text { percent }\end{array}$} & samples \\
No. & percent \\
\hline \hline 1 & 314 & $100 \%$ & 48 & $15.28 \%$ & 24 & $7.64 \%$ \\
\hline \hline
\end{tabular}

The researcher found the equality of the distribution among the students of the main sample of the research in the age - length - weight intelligence - the physical traits variables of the High

\section{Table (2)}

The statistical indications of the specifications of the two groups of the research: experimental and control in the main variables $N=48$

\begin{tabular}{c|c|c|c|c|c|c|c}
\hline \hline ser & $\begin{array}{c}\text { variables } \\
\begin{array}{c}\text { Growth } \\
\text { indications } \\
\text { rate }\end{array}\end{array}$ & Scale unit & $\begin{array}{c}\text { Arithmetic } \\
\text { average }\end{array}$ & mean & $\begin{array}{c}\text { Standard } \\
\text { deviation }\end{array}$ & Broadening & Bending \\
\hline \hline 1 & age & Year/month & 19.75 & 20.00 & 0.56 & $0.31-$ & $1.33-$ \\
\hline 2 & Length & $\mathrm{Cm}$ & 162.98 & 163.00 & 2.36 & $0.92-$ & $0.27-$ \\
\hline 3 & Weight & $\mathrm{Kg}$ & 63.60 & 63.00 & 3.26 & $0.08-$ & 0.84 \\
\hline \hline
\end{tabular}

Table ( 3)

The statistical indications of the specifications of the two groups of the research: experimental and control in the main variables $N=48$ 


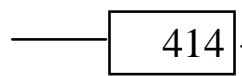

\begin{tabular}{l|c|c|c|c|c|c|c}
\hline \hline ser & variables & $\begin{array}{c}\text { Scale } \\
\text { unit }\end{array}$ & $\begin{array}{c}\text { Arithmetic } \\
\text { average }\end{array}$ & Mean & $\begin{array}{c}\text { Standard } \\
\text { deviation }\end{array}$ & Broadening & Bending \\
\hline \hline 1 & intelligence & Mark & 37.13 & 38.00 & 5.11 & $0.94-$ & $0.51-$ \\
\hline \hline
\end{tabular}

Table (4)

The statistical indications of the specifications of the two groups of the research: experimental and control in the main variables $\mathrm{N}=48$

\begin{tabular}{l|c|c|c|c|c|c|c}
\hline \hline ser & $\begin{array}{c}\text { variables } \\
\text { Physical } \\
\text { tests }\end{array}$ & $\begin{array}{c}\text { Scale } \\
\text { unit }\end{array}$ & $\begin{array}{c}\text { Arithmetic } \\
\text { average }\end{array}$ & Mean & $\begin{array}{c}\text { Standard } \\
\text { deviation }\end{array}$ & Broadening & Bending \\
\hline \hline 1 & speed & Second & 31.69 & 31.00 & 3.39 & $0.30-$ & 0.16 \\
\hline 2 & Ability & Cm & 5.47 & 5.43 & 0.19 & 3.46 & 1.73 \\
\hline 3 & Flexibility & Cm & 83.02 & 81.50 & 5.43 & $1.19-$ & $0.03-$ \\
\hline 4 & smartness & Second & 8.41 & 8.40 & 0.10 & $0.84-$ & 0.26 \\
\hline 5 & coherence & Mark & 2.63 & 3.00 & 0.85 & $0.37-$ & $0.38-$ \\
\hline \hline
\end{tabular}

Table (5)

The statistical indications of the specifications of the two groups of the research: experimental and control in the main variables $N=48$

\begin{tabular}{c|c|c|c|c|c|c|c}
\hline \hline ser & variables & $\begin{array}{c}\text { Scale } \\
\text { unit }\end{array}$ & $\begin{array}{c}\text { Arithmetic } \\
\text { average }\end{array}$ & mean & $\begin{array}{c}\text { Standard } \\
\text { deviation }\end{array}$ & Broadening & Bending \\
\hline \hline 1 & $\begin{array}{c}\text { Technical } \\
\text { level }\end{array}$ & Mark & 18.67 & 18.00 & 1.67 & $0.85-$ & 0.59 \\
\hline 1 & $\begin{array}{c}\text { Digital } \\
\text { level }\end{array}$ & $\mathrm{Cm}$ & 31.15 & 30.00 & 4.55 & $0.46-$ & 0.42 \\
\hline 1 & $\begin{array}{c}\text { Informational } \\
\text { acquisition } \\
\text { level }\end{array}$ & Mark & 9.60 & 9.00 & 2.20 & $0.02-$ & $0.54-$ \\
\hline \hline
\end{tabular}

From table (2-3-4-5), arithmetic average, mean, the standard deviation and bending coefficient are shown for the two groups of the research sample in the main variables, the data was moderate in distribution and the curve moderation similarity where the bending coefficient values

\section{Table (6)}

homogeneity and the differences indication among the pre standard variables for the two groups, control and experimental in the main variables of the research for showing equality $\mathrm{N1}=\mathrm{N2}=\mathbf{2 4}$ Assiut Journal For Sport Science Arts 


\begin{tabular}{|c|c|c|c|c|c|c|c|c|c|c|}
\hline \multirow[t]{2}{*}{ ser } & \multirow{2}{*}{$\begin{array}{c}\text { variables } \\
\text { Growth } \\
\text { indication } \\
\text { rate }\end{array}$} & \multirow{2}{*}{$\begin{array}{c}\text { Scale } \\
\text { unit }\end{array}$} & \multicolumn{2}{|c|}{$\begin{array}{c}\text { Control } \\
\text { group }\end{array}$} & \multicolumn{2}{|c|}{$\begin{array}{c}\begin{array}{c}\text { Experimental } \\
\text { group }\end{array} \\
\end{array}$} & \multirow{2}{*}{$\begin{array}{c}\text { Difference } \\
\text { among } \\
\text { averages }\end{array}$} & \multirow{2}{*}{$\begin{array}{l}\text { Homo } \\
\text { geneity }\end{array}$} & \multirow{2}{*}{$\begin{array}{c}(\mathbf{T}) \\
\text { value }\end{array}$} & \multirow{2}{*}{$\begin{array}{c}\text { Statistical } \\
\text { indication } \\
\text { level }\end{array}$} \\
\hline & & & $\mathbf{S}$ & A+- & $\mathbf{S}$ & A+- & & & & \\
\hline 1 & Age & Year/month & 19.71 & 0.62 & 19.79 & 0.51 & 0.08 & 1.50 & 0.51 & 0.61 \\
\hline 2 & length & $\mathrm{Cm}$ & 162.75 & 2.29 & 163.21 & 2.45 & 0.46 & 1.14 & 0.67 & 0.51 \\
\hline 3 & weight & $\mathrm{Kg}$ & 63.75 & 3.07 & 63.46 & 3.50 & 0.29 & 1.30 & 0.31 & 0.76 \\
\hline
\end{tabular}

\section{Table (7)}

homogeneity and the differences indication among the pre

standard variables for the two groups, control and experimental in the main variables of the research for showing equality $\mathrm{N} 1=\mathrm{N} 2=24$

\begin{tabular}{|c|c|c|c|c|c|c|c|c|c|c|}
\hline \multirow[t]{2}{*}{ ser } & \multirow[t]{2}{*}{ variables } & \multirow{2}{*}{$\begin{array}{c}\text { Scale } \\
\text { unit }\end{array}$} & \multicolumn{2}{|c|}{$\begin{array}{c}\text { Control } \\
\text { group }\end{array}$} & \multicolumn{2}{|c|}{$\begin{array}{c}\text { Experimental } \\
\text { group }\end{array}$} & \multirow{2}{*}{$\begin{array}{c}\text { Difference } \\
\text { among } \\
\text { averages }\end{array}$} & \multirow{2}{*}{$\begin{array}{l}\text { Homo } \\
\text { geneity }\end{array}$} & \multirow{2}{*}{$\begin{array}{c}(\mathbf{T}) \\
\text { value }\end{array}$} & \multirow{2}{*}{$\begin{array}{c}\text { Statistical } \\
\text { indication } \\
\text { level }\end{array}$} \\
\hline & & & $S$ & $A+-$ & $S$ & $A+-$ & & & & \\
\hline 4 & intelligence & Mark & 37.00 & 3.80 & 37.25 & 3.94 & 0.25 & 1.08 & 0.41 & 0.89 \\
\hline
\end{tabular}

\section{Table (8)}

homogeneity and the differences indication among the pre standard variables for the two groups, control and experimental in the main variables of the research for showing equality $N 1=N 2=24$

\begin{tabular}{|c|c|c|c|c|c|c|c|c|c|c|}
\hline \multirow[t]{2}{*}{ ser } & \multirow{2}{*}{$\begin{array}{c}\text { variables } \\
\text { Physical } \\
\text { tests }\end{array}$} & \multirow{2}{*}{$\begin{array}{c}\text { Scale } \\
\text { unit }\end{array}$} & \multicolumn{2}{|c|}{$\begin{array}{l}\begin{array}{c}\text { Control } \\
\text { group }\end{array} \\
\end{array}$} & \multicolumn{2}{|c|}{$\begin{array}{c}\begin{array}{c}\text { Experimental } \\
\text { group }\end{array} \\
\end{array}$} & \multirow{2}{*}{$\begin{array}{c}\text { Difference } \\
\text { among } \\
\text { averages }\end{array}$} & \multirow{2}{*}{$\begin{array}{l}\text { Homo } \\
\text { geneity }\end{array}$} & \multirow{2}{*}{$\begin{array}{c}(\mathrm{T}) \\
\text { value }\end{array}$} & \multirow{2}{*}{$\begin{array}{c}\text { Statistical } \\
\text { indication } \\
\text { level }\end{array}$} \\
\hline & & & $S$ & $A+-$ & $S$ & $A+-$ & & & & \\
\hline 1 & Speed & Second & 32.54 & 3.23 & 31.38 & 3.20 & 1.17 & 1.02 & 1.26 & 0.22 \\
\hline 2 & ability & $\mathrm{Cm}$ & 5.46 & 0.21 & 5.48 & 0.18 & 0.02 & 1.34 & 0.30 & 0.76 \\
\hline 3 & flexibility & Second & 83.08 & 5.64 & 82.96 & 5.33 & 0.13 & 1.12 & 0.08 & 0.94 \\
\hline 4 & Agility & Second & 8.39 & 0.10 & 8.44 & 0.12 & 0.05 & 1.49 & 1.57 & 0.12 \\
\hline 5 & coherence & Mark & 2.67 & 0.82 & 2.58 & 0.83 & 0.08 & 1.03 & 0.35 & 0.73 \\
\hline
\end{tabular}

\section{Table (9)}

homogeneity and the differences indicationamong the pre standard variables forthe two groups, control and experimentalin the main variables of the research for showing equality $\mathrm{N} 1=\mathrm{N} 2=\mathbf{2 4}$

\begin{tabular}{|c|c|c|c|c|c|c|c|c|c|c|}
\hline \multirow[t]{2}{*}{ ser } & \multirow[t]{2}{*}{ variables } & \multirow{2}{*}{$\begin{array}{c}\text { Scale } \\
\text { unit }\end{array}$} & \multicolumn{2}{|c|}{$\begin{array}{l}\text { Control } \\
\text { group }\end{array}$} & \multicolumn{2}{|c|}{$\begin{array}{c}\text { Experimental } \\
\text { group }\end{array}$} & \multirow{2}{*}{$\begin{array}{c}\text { Difference } \\
\text { among } \\
\text { averages }\end{array}$} & \multirow[t]{2}{*}{ Homogeneity } & \multirow{2}{*}{$\begin{array}{c}(\mathrm{T}) \\
\text { value }\end{array}$} & \multirow{2}{*}{$\begin{array}{c}\text { Statistical } \\
\text { indication } \\
\text { level }\end{array}$} \\
\hline & & & $\mathbf{S}$ & A+- & $\mathbf{S}$ & A+- & & & & \\
\hline 1 & $\begin{array}{c}\text { Technical } \\
\text { level }\end{array}$ & Mark & 18.54 & 1.61 & 18.79 & 1.74 & 0.25 & 1.17 & 0.61 & 0.52 \\
\hline 2 & Digital level & $\mathrm{cm}$ & 30.63 & 4.50 & 31.67 & 4.58 & 1.04 & 1.04 & 0.43 & 0.79 \\
\hline 3 & $\begin{array}{c}\text { Informational } \\
\text { acquisition } \\
\text { level }\end{array}$ & mark & 9.79 & 2.06 & 9.42 & 2.36 & 0.38 & 1.30 & 0.59 & 0.56 \\
\hline
\end{tabular}

The schedule $(\mathrm{F})$ value at abstract level 0.05 , and two freedom marks $(23,23)=2.01$, schedule $(\mathrm{T})$ value at abstract level $0.05=2.01$

It is shown from table (6-7-8-9) there are no 
differences with statistical indication among the pre scales of the two groups in the main variables of the research giving direct indication on the equality of the two groups in these variables

\section{Means f collecting data:}

Growth rates including:

Time age :by referring to the date of the birth to the nearest year

Length :by using the rest meter device to the nearest $\mathrm{cm}$ Weight :by using the medical scale to the nearest kilogram

Mental abilities : (intelligence test, IT), appendix (A)
The researcher used the intelligence test prepared by SamiaEl Ansary, appendix (A), it was selected as it is suitable for the age stage of the research and that it has high degree of validity and proof

Scientific coefficients of the mental abilities test (intelligence):

Validity coefficient:

And for finding the validity coefficient of the (IT), the researcher used the edge comparative method on a sample of (24) students from the research total and outside the main research sample table (10) show this

Table (10)

Differences indication between the two averages of the highest fourths and the lowest fourths of the intelligence test $\mathrm{N}=\mathbf{2 4}$

\begin{tabular}{|c|c|c|c|c|c|c|c|c|c|}
\hline \multirow[t]{2}{*}{ Ser } & \multirow[t]{2}{*}{ test } & \multicolumn{2}{|c|}{$\begin{array}{c}\text { Highest } \\
\text { fourths } N=6\end{array}$} & \multicolumn{2}{|c|}{$\begin{array}{c}\text { Lowest } \\
\text { fourths } \\
N=6\end{array}$} & \multirow[t]{2}{*}{$\begin{array}{c}\text { Averages } \\
\text { differences }\end{array}$} & \multirow[t]{2}{*}{$\begin{array}{c}T \\
\text { value }\end{array}$} & \multirow[t]{2}{*}{$\begin{array}{c}\text { Eta } \\
2\end{array}$} & \multirow[t]{2}{*}{$\begin{array}{c}\text { Validity } \\
\text { coefficient }\end{array}$} \\
\hline & & $\mathbf{S}$ & A+- & $\mathbf{S}$ & A+- & & & & \\
\hline$\overline{1}$ & Intelligence & 41.67 & $\overline{1.63}$ & 33.33 & 1.51 & 8.33 & 8.41 & 0.88 & 0.94 \\
\hline
\end{tabular}

T schedule value at abstract level $0.05=2.17$

From zero to less than $0.30=$ weak effect

From 0.30 to less than $0.50=$ moderate effect

From 0.50 and more $=$ strong effect

It is shown from table (10) that there are differences with statistical indications at abstract level 0.05 between the highest fourths and the lowest fourths averages in the technicians sample in the marks of the intelligence test, also the test proved that it had high power of effect and validity.

Proof coefficient: 
And for finding the proof coefficient of the IT, the researcher applied the test on $19 / 10 / 2015$ on a sample of (24) student from the research community and outside the main research sample, then it was reapplied after seven days on 26/10/2015, then the correlation coefficient was calculated among the results of the first and the second application, table (11) shows that

\section{Table (11)}

Correlation coefficient between the first application and the second application of the intelligence test for showing the proof coefficient $N=24$

\begin{tabular}{l|c|c|c|c|c|c}
\hline \hline \multirow{2}{*}{ Ser } & \multirow{2}{*}{ Test } & \multicolumn{2}{|c|}{$\mathbf{1}^{\text {st }}$ application } & \multicolumn{2}{|c|}{$\mathbf{2}^{\text {nd }}$ application } & \multirow{2}{*}{$\begin{array}{c}\text { Correlation } \\
\text { coefficient }\end{array}$} \\
\cline { 3 - 6 } & & $\mathbf{S}$ & $\mathbf{A + -}$ & $\mathbf{S}$ & $\mathbf{A + -}$ & \\
\hline 1 & Intelligence & 37.50 & 2.32 & 38.50 & 2.15 & 0,88 \\
\hline \hline
\end{tabular}

$\mathrm{R}$ schedule value on abstract level $0.05=0.40$

From table (11), it is shown that there is correlation with statistical indication between the first and second applications for the IT of the research for the technicians sample at abstract level 0.05 referring to the test proof

Tests of the physical traits of the High Jump Competition by the back method, appen. (B):

The researcher limited the physical traits of the High Jump Competition by the back method after returning to the reference studies (18), the scientific references (3) ( 1) (12) (16) ( 9) (7) (17)
The scientific coefficients of the physical traits tests of High Jump Competition by the back method validity coefficient (VC):

The researcher used the edge comparative method for finding the $\mathrm{VC}$ of the tests of the research and they were applied on a sample of (24) student from the research community and outside the main research sample on 20/10/2015 table ( 12 ) shows this.

Table (12)

Indication of differences between the averages of the highest and lowest fourths in the physical tests for showing the VC N $=24$

\begin{tabular}{|c|c|c|c|c|c|c|c|c|c|}
\hline \multirow[t]{2}{*}{ ser } & \multirow{2}{*}{$\begin{array}{c}\text { Physical } \\
\text { tests }\end{array}$} & \multicolumn{2}{|c|}{ HF N $=6$} & \multicolumn{2}{|c|}{ LF N=6 } & \multirow{2}{*}{$\begin{array}{c}\text { Averages } \\
\text { differences }\end{array}$} & \multirow{2}{*}{$\begin{array}{c}\mathbf{T} \\
\text { value }\end{array}$} & \multirow{2}{*}{$\begin{array}{c}\text { Eta } \\
2\end{array}$} & \multirow[t]{2}{*}{$\mathrm{VC}$} \\
\hline & & $\mathbf{S}$ & A+- & $\mathbf{S}$ & A+- & & & & \\
\hline
\end{tabular}




\begin{tabular}{l|c|c|c|c|c|c|c|c|c}
\hline \hline 1 & Speed & 5.14 & 0.19 & 5.67 & 0.23 & 0.53 & 7.88 & 0.86 & 0.93 \\
\hline 2 & Ability & 35.00 & 2.45 & 26.33 & 1.51 & 8.67 & 7.38 & 0.85 & 0.92 \\
\hline 3 & Flexibility & 89.50 & 2.41 & 76.50 & 2.45 & 13.00 & 9.27 & 0.90 & 0.65 \\
\hline 4 & Agility & 8.35 & 0.18 & 9.51 & 0.26 & 1.16 & 8.14 & 0.87 & 0.93 \\
\hline 5 & Coherence & 3.50 & 0.55 & 1.33 & 0.52 & 2.17 & 7.05 & 0.83 & 0.91 \\
\hline \hline
\end{tabular}

T schedule value at abstract level $0.05=2.17$

It is shown from table (12) that there are differences with statistical indication at abstract level 0.05 between the two averages of the HF and LF for the technicians sample in the physical tests variables of the research, also it is shown that the tests were highly effective and valid.

Proof coefficient (PC):

And for finding the PC

of the tests of the research, the researcher applied the tests on 20/10/2015 and reapplied them after seven days on $27 / 10 / 2015$ on a sample of (24) students from the research community and outside the main research sample, then the correlation coefficient among the first and second applications was calculated, table (13) shows that

\section{Table (13)}

Correlation coefficient between the first application and second application in the physical tests for showing the proof coefficient $N=24$

\begin{tabular}{c|l|c|c|c|c|c}
\hline \hline \multirow{2}{*}{ Ser. } & \multirow{2}{*}{$\begin{array}{c}\text { Physical } \\
\text { tests }\end{array}$} & \multicolumn{2}{|c|}{$\mathbf{1}^{\text {st }}$ application } & \multicolumn{2}{|c|}{\begin{tabular}{|}
$2^{\text {nd }}$ \\
application
\end{tabular}} & \multirow{2}{*}{$\begin{array}{c}\text { Corr. } \\
\text { Coeffi. }\end{array}$} \\
\cline { 3 - 6 } & & $\mathbf{S}$ & $\mathbf{A + -}$ & $\mathbf{S}$ & $\mathbf{A + -}$ & \\
\hline \hline 1 & Speed & 5.41 & 0.27 & 5.37 & 0.32 & 0.93 \\
\hline 2 & Ability & 30.67 & 2.98 & 31.35 & 2.53 & 0.87 \\
\hline 3 & Flexibility & 83.00 & 3.26 & 84.25 & 3.68 & 0.86 \\
\hline 4 & Agility & 8.93 & 0.33 & 8.86 & 0.27 & 0.92 \\
\hline 5 & Coherence & 2.42 & 0.67 & 2.44 & 0.56 & 0.91 \\
\hline \hline
\end{tabular}

$\mathrm{T}$ schedule value at abstract level $0.05=0.40$

It is shown from table (13) that there is a correlation with statistical indication between the first and the second application in the physical tests in the technicians sample at abstract level 0.05 referring to the test proof.
Form of evaluating the technical performance level of High Jump Competition by the back method, appen. (D):

The researcher designed evaluation form for the technical performance level 
of High Jump Competition by the back method by referring to the scientific references (3) (5) (9) (7)(4) and the reference studies(1) (10) (17) , a mark was limited for every stage in the technical stages of the competition from $(0: 3)$ then the form in its initial shape was submitted to messers arbiters appen. (c) and amendment was made according to their views, so the form became in its final form appen. (D)

The scientific coefficient of the technical performance level evaluation of High Jump Competition by the back method:

Validity of arbiters: The

researcher submitted the form in its initial form appen.. (c) To messers arbiter to say their opinions and amendments were made then it was submitted another time to them and they approved it to percentage of $100 \%$

Validity coefficient (VC):

The differences indication between the HF and $\mathrm{LF}$ was used to find the VC of the form and it was applied on $20 / 10 / 2015$ on a sample consisting of (24) students from the research community and outside the main research sample where the researcher teach the exploratory sample students the High Jump Competition by the back method in the beginning of the first term and table (14) shows that.

Table (14)

Differences indication between the two averages of HF and LF In the variable of the technical performance level for showing the validity coefficient $N=24$

\begin{tabular}{|c|c|c|c|c|c|c|c|c|c|}
\hline \multirow{2}{*}{ Ser. } & \multirow{2}{*}{ variable } & \multicolumn{2}{|c|}{ HF $N=6$} & \multicolumn{2}{|c|}{ LF N=6 } & \multirow{2}{*}{$\begin{array}{l}\text { Average } \\
\text { differences }\end{array}$} & \multirow{2}{*}{$\begin{array}{l}\text { T } \\
\text { value }\end{array}$} & \multirow{2}{*}{$\begin{array}{l}\text { Eta } \\
2\end{array}$} & \multirow[t]{2}{*}{ VC } \\
\hline & & $\mathbf{S}$ & A+- & $\mathbf{S}$ & A+- & & & & \\
\hline 1 & $\begin{array}{l}\text { Technical } \\
\text { performance } \\
\text { level }\end{array}$ & 23.17 & 1.31 & 18.67 & 1.14 & 4.50 & 5.18 & 0.77 & 0.88 \\
\hline
\end{tabular}

T schedule value at abstract level is. $05=2.17$

It is shown from table

(14) that there are differences with statistical indication at abstract level.05 between the averages of $\mathrm{HF}$ and $\mathrm{LF}$ in the technicians sample in the variable of the technical performance level, referring to that the form of the research has high effect and validity.

Form proof (FP):

And for finding the FP coefficient, the researcher applied the form on 20/10/2015 and reapplied it after seven days on $27 / 10 / 2015$ on a sample of (24) students from 
the research community and outside the main research sample and the correlation coefficient between the results of the first and second applications was calculated, table (15) shows that.

Table (15)

Correlation coefficient between the first and the second application of the technical performance level for showing the proof coefficient $\mathrm{N}=\mathbf{2 4}$

\begin{tabular}{l|l|l|r|r|r|l}
\hline \hline \multirow{2}{*}{ Ser. } & \multirow{2}{*}{ Variable } & \multicolumn{2}{|c|}{$\mathbf{1}^{\text {st }}$} & \multicolumn{2}{c|}{$\begin{array}{c}\mathbf{2}^{\text {nd }} \\
\text { application }\end{array}$} & \multicolumn{2}{|c}{$\begin{array}{c}\text { application } \\
\text { Correlation } \\
\text { coefficient }\end{array}$} \\
\cline { 3 - 6 } & $\mathbf{S}$ & $\mathbf{A + -}$ & $\mathbf{S}$ & $\mathbf{A + -}$ & \\
\hline \hline 1 & $\begin{array}{l}\text { Technical } \\
\text { performance level }\end{array}$ & 18.92 & 1.74 & 19.00 & 1.75 & 0.89 \\
\hline \hline
\end{tabular}

T schedule value at abstract level $0.05=0.40$

It is shown from the table (15) that there is correlation with statistical indication between the first and second application (reapplying the test) in the technical performance level variable in the technicians sample at abstract level 0.05 referring to the test proof

The informational test of High Jump Competition by back method in its initial form appen. (H):

The researcher designed the informational acquisition test for High Jump Competition by back method for the students of the second year in the physical education faculty in Tanta after reviewing the scientific references (2)
(11), and the reference studies (15) (6) (19)

\section{Limiting the aim of the test:}

The test aims at measuring the acquisition of the students of the second year (the research sample) in the (technical stages - law common technical mistakes and ways of correcting them educational steps) for High Jump Competition by back method

Limiting the main axes of the test: The researcher defined the informational test axes of the research which are (technical stages- lawcommon technical mistakes and ways of correcting them educational steps) for High Jump Competition by back method 
Limiting the relative of the arbiters Appen. (i) importance of the around the relative importance informational test axes:

The researcher prepared a form to review the opinions of the each axis of the informational test axes, table (16) shows that

\section{Table (16)}

The relative importance of each axis of the informational test axes of the High Jump Competition by back method

\begin{tabular}{c|c|c}
\hline \hline Ser. & Axes & Relative importance \\
\hline \hline 1 & Technical stages & $51 \%$ \\
\hline 2 & Law & $22 \%$ \\
\hline 3 & Technical mistakes & $16 \%$ \\
\hline 4 & Educational steps & $11 \%$ \\
\hline \hline
\end{tabular}

Limiting the scientific material of the test:

in the levels of Test instructions: It must (knowledge - understanding application) according to Blom division of the aims in the informational field

Formalizing the test vocabulary: The researcher formalized the test vocabulary whose number is (55) one, appen. $(\mathrm{H})$ and it was regarded that the test vocab. is overall and featured by clearness and scientific accuracy and that they are suitable for the students levels

Limiting the questions:

multi choices one (three include the writing to the data of the students and not leaving any question without answer and also not giving more than one answer to one question with presenting a model answer.

Preparing the initial phase of the informational test Appen. (H): The initial phase of the informational test was presented to messers arbiter appen. (i) and the questions that obtained a rate of $75 \%$ of the total experts opinions were taken .table (17) shows that choices)

Table (17)

The initial and final number and the numbers of the excluded phrases of the test

\begin{tabular}{c|c|c|c|c|c}
\hline \hline Ser. & Test axes & $\begin{array}{c}\text { Initial } \\
\text { No. of }\end{array}$ & $\begin{array}{c}\text { Excluded } \\
\text { phrases }\end{array}$ & $\begin{array}{c}\text { No. of } \\
\text { EP }\end{array}$ & $\begin{array}{c}\text { Final } \\
\text { phrase }\end{array}$ \\
\hline \hline & \multicolumn{3}{|c}{ Assiut Journal For Sport Science Arts } & & \\
& &
\end{tabular}




\begin{tabular}{c|c|c|c|c|c}
\hline \hline & & phrases & (EP) No. & & No \\
\hline \hline 1 & Technical stages & 28 & 2 & 5,10 & 26 \\
\hline 2 & Law & 12 & - & - & 12 \\
\hline 3 & Technical mistakes & 10 & 2 & 45,48 & 8 \\
\hline 4 & Educational steps & 5 & 1 & 53 & 4 \\
\hline & Total & 55 & 5 & 5 & 50 \\
\hline \hline
\end{tabular}

It is shown from table

(17) the initial and final number and the numbers of the excluded phrases of the informational acquisition

Final phase of the informational acquisition test of High Jump Competition by the back method, append (F):

The researcher presented the informational acquisition testin its final phase to messers experts, append. $(\mathrm{H})$ and they approved the informational test in its final phase(arbiters validity) .

No. of individuals who gave correct answer for every vocab. $\mathbf{E C}=$

$\mathrm{DC}=1-\mathrm{EC}$

\section{Total number of individuals}

Uniqueness coefficient (UC):

$\mathbf{U C}=\mathrm{EC} \times \mathrm{DC}$ and the table (18) shows the coefficients of easiness,
Key of correcting the informational acquisition test of High Jump Competition by back method, append. (G):

the key of correcting the test was prepared, append. (G)

Analyzing the vocab. of informational acquisition test of High Jump Competition by the back method:

Easiness coefficient (EC): EC was calculated of the test through the following equation:

Table (18)

Coefficients of easiness, difficulty, and uniqueness of the vocab. of the informational acquisition test of the High Jump Competition by the back method 


\begin{tabular}{c|c|c|c|c|c|c|c}
\hline $\begin{array}{c}\text { Phrase } \\
\text { No }\end{array}$ & EC & DC & UC & $\begin{array}{c}\text { Phrase } \\
\text { No }\end{array}$ & EC & DC & UC \\
\hline \hline 1 & 0.583 & 0.417 & 0.243 & 26 & 0.500 & 0.500 & 0.250 \\
\hline 2 & 0.417 & 0.5836 & 0.243 & 27 & 0.670 & 0.330 & 0.221 \\
\hline 3 & 0.333 & 0.667 & 0.222 & 28 & 0.500 & 0.500 & 0.250 \\
\hline 4 & 0.667 & 0.333 & 0.222 & 29 & 0.375 & 0.625 & 0.234 \\
\hline 5 & 0.417 & 0.583 & 0.243 & 30 & 0.583 & 0.417 & 0.243 \\
\hline 6 & 0.333 & 0.667 & 0.222 & 31 & 0.333 & 0.667 & 0.222 \\
\hline 7 & 0.670 & 0.330 & 0.221 & 32 & 0.625 & 0.375 & 0.234 \\
\hline 8 & 0.625 & 0.375 & 0.234 & 33 & 0.417 & 0.583 & 0.243 \\
\hline 9 & 0.375 & 0.625 & 0.234 & 34 & 0.375 & 0.625 & 0.234 \\
\hline 10 & 0.500 & 0.500 & 0.250 & 35 & 0.625 & 0.375 & 0.234 \\
\hline 11 & 0.230 & 0.670 & 0.221 & 36 & 0.458 & 0.542 & 0.248 \\
\hline 12 & 0.625 & 0.375 & 0.234 & 37 & 0.333 & 0.667 & 0.222 \\
\hline 13 & 0.458 & 0.542 & 0.248 & 38 & 0.670 & 0.330 & 0.221 \\
\hline 14 & 0.500 & 0.500 & 0.250 & 39 & 0.330 & 0.670 & 0.221 \\
\hline 15 & 0.542 & 0.458 & 0.248 & 40 & 0.500 & 0.500 & 0.250 \\
\hline 16 & 0.375 & 0.625 & 0.234 & 41 & 0.625 & 0.375 & 0.234 \\
\hline 17 & 0.670 & 0.330 & 0.221 & 42 & 0.375 & 0.625 & 0.234 \\
\hline 18 & 0.625 & 0.375 & 0.234 & 43 & 0.500 & 0.500 & 0.250 \\
\hline 19 & 0.500 & 0.500 & 0.250 & 44 & 0.330 & 0.670 & 0.221 \\
\hline 20 & 0.333 & 0.667 & 0.222 & 45 & 0.458 & 0.542 & 0.248 \\
\hline 21 & 0.583 & 0.417 & 0.243 & 46 & 0.330 & 0.670 & 0.221 \\
\hline 22 & 0.667 & 0.333 & 0.222 & 47 & 0.500 & 0.500 & 0.250 \\
\hline 23 & 0.417 & 0.583 & 0.243 & 48 & 0.375 & 0.625 & 0.234 \\
\hline 24 & 0.625 & 0.375 & 0.234 & 49 & 0.500 & 0.500 & 0.250 \\
\hline 25 & 0.542 & 0.458 & 0.248 & 50 & 0.330 & 0.670 & 0.221 \\
\hline \hline
\end{tabular}

It is shown from table (18) that the informational test is distinguished by easiness coefficients where they range from $(333.0$ - 667.0), the DC

\section{Limiting the test time:}

time taken by first student + time taken by last student

\section{Test time $=$}


So we could limit the test time and it was 40 minutes The scientific coefficients of the informational acquisition test IAT of High Jump Competition by back method:

Informational test validity coefficient (ITVC):
The researcher calculated the ITVC of the research on a sample of (24) students from the research community and outside the main research sample on 19/10/2015 and the HF and LF were calculated, table (19) shows this

Table (19)

Differences indication between the averages of the $\mathrm{HF}$ and $\mathrm{LF}$ in the IAT variable of High Jump Competition by the back method $\mathrm{N}=\mathbf{2 4}$

\begin{tabular}{|c|c|c|c|c|c|c|c|c|c|}
\hline \multirow{2}{*}{ Ser. } & \multirow{2}{*}{ variable } & \multicolumn{2}{|c|}{ HF $N=6$} & \multicolumn{2}{|c|}{ LF $\quad \mathrm{N}=6$} & \multirow{2}{*}{$\begin{array}{l}\text { Aver } \\
\text { Diff. }\end{array}$} & \multirow{2}{*}{$\begin{array}{c}T \\
\text { value }\end{array}$} & \multirow{2}{*}{$\begin{array}{c}\text { Eta } \\
2\end{array}$} & \multirow{2}{*}{ VC } \\
\hline & & $\mathbf{S}$ & A+- & $\mathbf{S}$ & A+- & & & & \\
\hline 1 & $\begin{array}{l}\text { Informational } \\
\text { acquisition }\end{array}$ & 17.5 & 0.89 & 8.50 & 2.00 & 9.00 & 10.06 & 0.91 & 0.95 \\
\hline
\end{tabular}

T schedule value at abstract level $0.05=2.17$

It is shown from table (19) that there are differences with statistical indication between $\mathrm{HF}$ and $\mathrm{LF}$ in the exploratory study sample in the ITV at abstract level 0.05 referring to the ITV of the research.

Proof of informational test of the research:

The researcher calculated the informational test proof by applying it on a sample of (24) student from the research community and outside the main research sample on $19 / 10 / 2015$ then the test was reapplied on the same sample after (7) days on $26 / 10 / 2015$ then the correlation coefficient was calculated between their marks, table (20) shows that

Table (20)

Correlation coefficient between the first and second application of the IAT of HJC by the back method $\mathrm{N}=24$

\begin{tabular}{|c|c|c|c|}
\hline Ser & \begin{tabular}{l|l|l} 
& $1^{\text {st }}$ application & $2^{\text {IIt }}$ \\
\end{tabular} & application & Correlation \\
\hline & Assiut Journal For Sport Science Arts & & \\
\hline
\end{tabular}




\begin{tabular}{c|c|c|c|c|c|c}
\hline & & $\mathbf{S}$ & $\mathbf{A + -}$ & $\mathbf{S}$ & $\mathbf{A + -}$ & coefficient \\
\hline \hline 1 & $\begin{array}{c}\text { Informational } \\
\text { acquisition }\end{array}$ & 13.00 & 2.49 & 13.75 & 1.89 & 0.89 \\
\hline \hline
\end{tabular}

$\mathrm{R}$ schedule value at abstract value $0.05=0.40$

It is shown from table (20) that there is correlation with statistical indication between the first and second applications in the I $\mathrm{T}$ variable on the exploratory study sample at abstract level 0.05 referring to the proof of the informational test

Educational program of High Jump by back method by using Wheetly model for constructive learning:

Aims of the educational program:

Informational aim:

The suggested program aims at giving the students of the second year at the physical education faculty in Tanta (the technical stages - competition rules - common technical mistakes and method of correcting them - educational steps) of the High Jump Competition by back method Skill aim:

1) It is represented in teaching the students how to perform the technical stages of the High Jump Competition by back method

2) Achieving the highest possible height

Time framework of carrying out the suggested educational program :

The researcher applied the educational program in (5) applied lectures by a lecture weekly and the time of the lecture is (120) minutes, (5) theoretical lectures by a lecture weekly and the lecture time is (60) minutes according to the study plan

The exploratory study of the suggested

program:

educational

The researcher applied the educational program by using Wheetly program for constructive learning on a sample of (24) student from the research community and outside the research main sample in the period from $26 / 10 / 2015$ to $29 / 10 / 2015$ to recognize its suitability to their abilities and the extent of their understanding to the questions and testing the validity of the place.

\section{Pre measurements:}

The

researcher performed the suggested educational program by Wheetly model for constructive learning on the experimental group, the followed educational program (explaining and presentation) on the control group, the execution of the program took five weeks by (5) applied lectures, one lecture per week, the period of the lecture is (120) minutes, (5) theoretical 
lectures, one per week, period (60) minutes in the period from $5 / 11 / 2015$ to $3 / 12 / 2015$

The post measurements:

The

performed researcher measurements after carrying out the educational program on the control and experimental groups in (technical performance level - digital level - IAL) for High Jump Competition by back method on $4 / 12 / 2015,5 / 12 / 2015$ with the same order and conditions of the pre measurements
The used
statistical handlings:

- Arithmetic mean -

Standard deviation -
- Bending coefficient Uniqueness coefficient -Bending coefficient - Uniqueness coefficient Easiness and difficulty coefficient- (T) test-

Improvement rate

Results presentation:

The researcher will present her results as follows:

1) Presenting the first supposition results "there are differences with statistical indication between the averages of the pre and post measurements of the control group in the technical performance level, digital level, IAL of High Jump Competition by the back method for the post measurement"

Table (21)

Differences indication and improvement Rates between the pre and post measurement of the control group in the main research variables $\mathrm{N}=2$

\begin{tabular}{|c|c|c|c|c|c|c|c|c|c|c|}
\hline \multirow[t]{2}{*}{ Ser. } & \multirow[t]{2}{*}{ variables } & \multicolumn{2}{|c|}{ Pre app. } & \multicolumn{2}{|c|}{ Post app. } & \multirow{2}{*}{$\begin{array}{l}\text { Aver. } \\
\text { diff. }\end{array}$} & \multirow{2}{*}{$\begin{array}{c}\text { Stand. } \\
\text { mist. } \\
\text { of } \\
\text { average }\end{array}$} & \multirow{2}{*}{$\begin{array}{c}\mathbf{T} \\
\text { value }\end{array}$} & \multirow{2}{*}{$\begin{array}{l}\text { Statistical } \\
\text { indication }\end{array}$} & \multirow{2}{*}{$\begin{array}{l}\text { Improve. } \\
\text { rate }\end{array}$} \\
\hline & & $\mathbf{S}$ & A+- & $\mathbf{S}$ & A+- & & & & & \\
\hline 1 & $\begin{array}{c}\text { Technical } \\
\text { level }\end{array}$ & 18.54 & 1.61 & 36.13 & 3.53 & 17.58 & 1.98 & 8.90 & 0.00 & 94.83 \\
\hline 1 & $\begin{array}{c}\text { Digital } \\
\text { level }\end{array}$ & 30.63 & 4.50 & 60.00 & 8.21 & 29.38 & 2.03 & 14.50 & 0.00 & 95.92 \\
\hline 1 & IAL & 9.79 & 2.06 & 30.08 & 4.91 & 20.29 & 2.03 & 10.02 & 0.00 & 207.23 \\
\hline
\end{tabular}

T schedule value at abstract level $0.05=1.71$

It is shown from table (21) that there are differences with statistical indication at abstract level 0,05 between the pre and post measurements for the control group in the main research variables where the calculated (T) ranged from $(8.28-15.16)$ which is higher than (t) schedule value, also the improvement rate achieved a

Assiut Journal For Sport Science Arts 
value between $(144.44 \%$ -

$207.23 \%)$

Table (22)

Abstract of effect size in the main research variables of the control group of the research according to Kohean equations

\begin{tabular}{|c|c|c|c|c|c|c|}
\hline $\begin{array}{l}\text { Statistical ind. } \\
\text { variables }\end{array}$ & $\begin{array}{c}\text { Scale } \\
\text { unit }\end{array}$ & $\begin{array}{l}(\mathrm{T}) \\
\text { value }\end{array}$ & $\begin{array}{l}\text { Ind. } \\
\text { Level }\end{array}$ & Eta 2 & $\begin{array}{l}\text { Effect } \\
\text { size }\end{array}$ & $\begin{array}{c}\text { Effect } \\
\text { size ind. }\end{array}$ \\
\hline Technical level & Mark & 8.28 & 0.00 & 0.75 & 1.64 & High \\
\hline Digital level & $\mathrm{cm}$ & 9.23 & 0.00 & 0.79 & 1.72 & High \\
\hline IA standard & Mark & 10.02 & 0.00 & 0.81 & 2.11 & High \\
\hline \multicolumn{3}{|c|}{$\begin{array}{l}\text { Effect size standards:- } 0.20 \text { : low } \\
\text { It is shown from table } \\
\text { (16) that the effect size values } \\
\text { in the main research variables } \\
\text { achieved values more than } \\
\text { (0.80) which is high indication } \\
\text { referring to the relative effect } \\
\text { of the handling used in the } \\
\text { (followed educational } \\
\text { program) on the affiliated } \\
\text { variable and that the effect size } \\
\text { of the followed program } \\
\text { (explaining and presentation) }\end{array}$} & \multicolumn{4}{|c|}{$\begin{array}{l}\text { 0.50: average } 0.80 \text { high } \\
\text { 2) Presenting the second } \\
\text { proposition results " there are } \\
\text { differences with statistical } \\
\text { indication between the two } \\
\text { averages of the pre and post } \\
\text { averages for the experimental } \\
\text { group in the technical } \\
\text { performance level, digital level } \\
\text { and the IAL of High Jump } \\
\text { Competition by the back } \\
\text { method for the post } \\
\text { measurement " }\end{array}$} \\
\hline
\end{tabular}

Table (23)

Differences indication and rates of improvement In the pre and post measurement of the experimental group in the main research variables $\mathrm{N}=\mathbf{2 4}$

\begin{tabular}{l|c|c|c|c|c|c|c|c|c|c}
\hline \hline \multirow{2}{*}{ Ser. } & Variables & \multicolumn{2}{|c|}{ Pre app. } & \multicolumn{2}{|c|}{ Post app. } & $\begin{array}{c}\text { Ave. } \\
\text { diff. }\end{array}$ & $\begin{array}{c}\text { Stand. } \\
\text { Mist. } \\
\text { of } \\
\text { aver. }\end{array}$ & $\begin{array}{c}\text { T } \\
\text { value }\end{array}$ & $\begin{array}{c}\text { Statistical } \\
\text { indication }\end{array}$ & $\begin{array}{c}\text { Improve. } \\
\text { Rate \% }\end{array}$ \\
\cline { 3 - 10 } & S & A+- & S & A+- & & & \\
\hline \hline 1 & $\begin{array}{c}\text { Technical } \\
\text { level }\end{array}$ & 18.79 & 1.74 & 46.17 & 2.81 & 27.38 & 2.04 & 13.43 & 0.00 & 145.68 \\
\hline 2 & Digital level & 31.67 & 4.58 & 98.13 & 5.28 & 66.46 & 2.43 & 27.38 & 0.00 & 209.87 \\
\hline 3 & IAL & 9.42 & 2.36 & 42.79 & 2.86 & 33.38 & 1.25 & 26.77 & 0.00 & 354.42 \\
\hline \hline
\end{tabular}

T schedule value at abstract level $0.05=1.71$

It is shown from the

table (23) that there are differences with statistical indication at abstract level 0.05 between the pre and post measurement of the

experimental group in the main research variables where calculated (T) achieved a value between (16.94-26.77) which is more than (T) schedule value, also the 
improvement percentage

Table (24)

achieved (249.02\%-354.42\%)

Abstract of effect size in the main research variables of the experimental research group according to Kohean equations

\begin{tabular}{l|c|c|c|c|c|c}
\hline \hline $\begin{array}{c}\text { Statistical } \\
\text { ind. } \\
\text { variables }\end{array}$ & $\begin{array}{c}\text { Scale } \\
\text { unit }\end{array}$ & $\begin{array}{c}(\mathbf{T}) \\
\text { value }\end{array}$ & $\begin{array}{c}\text { Indi. } \\
\text { Stan }\end{array}$ & Eta 2 & $\begin{array}{c}\text { Effect } \\
\text { size }\end{array}$ & Eff.size.indi. \\
\hline \hline Technical level & Mark & 13.43 & 0.00 & 0.89 & 2.58 & High \\
\hline $\begin{array}{l}\text { Digital } \\
\text { level }\end{array}$ & $\mathrm{cm}$ & 27.38 & 0.00 & 0.97 & 3.47 & High \\
\hline IAL & Mark & 26.77 & 0.00 & 0.97 & 3.91 & High \\
\hline \hline
\end{tabular}

Effect size levels: 0.20 : low

It is shown from schedule (24)

0.50: moderate

0.80: high

that the effect size values in the

differences with statistical

IAT achieved a value more than (0.80) which is a high indication referring to the relative effect of the used experimental handling (for the suggested educational program) on the affiliated variable and that the program effect size is strong.

3) Presenting the results of the third supposition "there are

\section{Table (25)}

Differences indication between the averages of the post measurements and the differences of the improvement rates of the control and experimental groups in the main research variables $\mathrm{N} 1=\mathrm{N} 2=24$

\begin{tabular}{|c|c|c|c|c|c|c|c|c|c|}
\hline \multirow{2}{*}{ Ser. } & \multirow[t]{2}{*}{ variables } & \multicolumn{2}{|c|}{$\overline{\text { Control group }}$} & \multicolumn{2}{|c|}{ Exper. Group } & \multirow{2}{*}{$\begin{array}{l}\text { Diff bet. } \\
\text { average }\end{array}$} & \multirow{2}{*}{$\begin{array}{l}\text { T } \\
\text { value }\end{array}$} & \multirow{2}{*}{$\begin{array}{l}\text { Stat. } \\
\text { ind. }\end{array}$} & \multirow{2}{*}{$\begin{array}{l}\text { Improve. } \\
\text { Diff. rate }\end{array}$} \\
\hline & & $\mathbf{S}$ & A+- & $\mathbf{S}$ & A+- & & & & \\
\hline 1 & Technical level & 36.13 & 3.53 & 46.17 & 2.81 & 10.04 & 10.67 & 0.00 & 50.84 \\
\hline 1 & Digital level & 60.00 & 8.21 & 98.13 & 5.28 & 38.13 & 18.73 & 0.00 & 113.95 \\
\hline 1 & IAL & 30.08 & 4.91 & 42.79 & 2.86 & 12.71 & 10.77 & 0.00 & 147.19 \\
\hline
\end{tabular}

(T) schedule value at abstract level $0.05=1.68$

It is shown from table

of the post measurements of

(25) that there are no differences with statistical indication among the averages the control and experimental groups of the research in the Assiut Journal For Sport Science Arts 
abstract level 0.05 for the experimental group where $(\mathrm{T})$ calculated value achieved (7.38-14.34) which are more than $(\mathrm{T})$ schedule value, also the differences of the percentages of the improvement achieved value of $(104.58 \%-178.06 \%)$

Table (26)

Abstract of effect size in the the main research variables for the control and experimental groups of the research according to Kohean equations

\begin{tabular}{l|c|c|c|c|c|c}
\hline \hline $\begin{array}{l}\text { Variable } \\
\text { statistical } \\
\text { indication }\end{array}$ & $\begin{array}{c}\text { Scale } \\
\text { unit }\end{array}$ & $\begin{array}{c}\text { T } \\
\text { value }\end{array}$ & $\begin{array}{c}\text { Ind. } \\
\text { Lev. }\end{array}$ & Eta 2 & $\begin{array}{c}\text { Eff. } \\
\text { Size }\end{array}$ & $\begin{array}{c}\text { Eff.size } \\
\text { ind. }\end{array}$ \\
\hline \hline Technical level & Mark & 10.67 & 0.00 & 0.71 & 1.69 & High \\
\hline Digital level & cm & 18.73 & 0.00 & 0.88 & 2.71 & High \\
\hline IAL & Mark & 10.77 & 0.00 & 0.71 & 2.56 & High \\
\hline \hline
\end{tabular}

Effect size levels: 0.20: low

It is shown from the table (26) that the effect size values in the the main research variables achieved a value more than $(0.80)$ which is a high indication referring to the relative effect of the experimental handling used in the (suggested educational program) better than the handling used in the program (the followed educational one) on the affiliated variable

Results discussion:

Depending on the results to which we reached and which were handled statistically, the researcher will discuss the results according to:

It is shown from the results of the two tables $(21,22)$
0.50: moderate 0.80: high

there are differences with statistical indication between the pre and post measurements for the control group in the technical performance level of High Jump competition by the back method where calculated (T) reached 8.90 which is more than (T) schedule value at abstract level $0.05=1.71$ by percentage $94.83 \%$ and it achieved the effect size value 1.64

The researcher ascribe the improvement of the control group in the technical performance level of High Jump competition by back method to that the teacher used the followed way (explaining and model performance), then 
the students imitated the model They exchange the ideas in every stage of the technical stages of the competition of the research which is approaching, ascending, flying and landing with the teacher correcting the technical mistakes then repeating the performance by students to correct the mistakes in them then correcting leading to the improvement of the technical performance level for the students in the competition, these results are accordant to the study of Osama Ahmed (2001) (1)، Meleody mohamed (2015) (19) whose their studies highlighted that there is progress in the skill standard Also it is shown from the results of the tables $(21,22)$ that there are differences with statistical indication between the pre and post scales of the control group in the digital level of High Jump competition by back method where calculated (T) achieved a value which is $=9.23$ which is more than $(\mathrm{T})$ schedule value at abstract level $0.05=1.71$ with percentage of $145.94 \%$ and the effect size value achieved 0.79 The researcher ascribes the improvement of the control group in the digital level of
High Jump competition by back method to the technical level improvement of the competition, in this respect, Bastawisi Ahmed EL Hosini (1997) refers to that Verchosaniky and his field researches of the jump competitions generally proved that the improvement of technique has importance at the digital level of the jump (3:270)

It is shown also from the results of the tables $(15,16)$ that there are differences with statistical indication between the pre and post scales of the control group at the IAL of High Jump competition by back method, where calculated (T) achieved a value of 10.02 which more than $(\mathrm{T})$ schedule value at abstract level $0.05=1.71$ with percentage $207.23 \%$ achieving effect size value 2.11

The researcher refers the improvement of the control group in the IAL of the High Jump competition by back method to the style followed in the theoretical teaching which is explanation by the teacher including giving the theoretical information to the students represented in the (technical stages - law - common 
technical mistakes and the ways of correcting them and the educational steps) of the competition of the research, in this respect, Zakia Ebrahim and others (2002) mention that teaching by using the followed method leads to increasing the student level as a result of practice and repeated performance during the learning process leading to providing the students with information and knowledge about the learned skills (4:80)

These results is accordant to the results of the study of Bek Walkom Ritse (2001) (25), Fransioz (2001) (22), Zombash and Riman (2002) (27), Melody Mohamed (2015) (19), thus we ascertain the validity of the first proposition providing "there are differences with statistical indication between the averages of the pre and post scales of the control group in the technical performance level, the digital level and IAL of High Jump competition by the back method for the post scale"

It is shown from the results of the tables $(23,24)$ that there are differences with statistical indication between the pre and post scales of the experimental group in the technical performance level of High Jump competition by back method where calculated (T) achieved a value of 13.43 which is more than schedule value at abstract level $0.05=1.71$ with percentage $145.68 \%$ achieving effect size value of 2.58

The researcher refers the improvement of the experimental group in the technical performance level of the competition of the research to using Wheetly model for constructive learning through which the students were divided into small groups in which students cooperate with each other and They exchange the ideas in every stage of the technical stages of the competition of the research which is approaching, ascending, flying and landing till reaching to the problem solving and performing the educational exercises related to every stage of the technical stages and exchange ideas to reach to problem solving under supervision of the teacher leading to the increase of the students motivation toward learning,also the students advance in the educational program according to their 
abilities and this increase the communications among the students These results are accordant to the study of Melody Mohamed (2015) (19) referring to that using Wheetly model has positive effect on the technical performance level of hockey skills. In this respect, Yehia Abo Harb and others (2004) refer to that the valid learning is based on the active role of the learner and his ability to have insight and think in the educational environment (20:39).

Also it is shown from the table $(23,24)$ that there are differences with statistical indication between the pre and post scale of the experimental group in the digital level of HJc by the back method where (T) calculated value reached 27.38 which more than (T) schedule value at abstract level $0.05,1.71$, with percentage $209.87 \%$ and effect size value achieved 3.47

The researcher ascribe the improvement of the experimental group in the digital level of the research competition to the improvement of the technical performance level which has a positive effect on the digital level. Also it is shown from table $(23,24)$ that there are differences with statistical indication between the pre and post scales for the experimental group in the IAL in the High Jump competition by back method where $(\mathrm{T})$ calculated value reached 26.77 which are more than $(\mathrm{T})$ schedule value at abstract level $0.05=1.71$ with percentage $354 \%$ and the effect size value achieved 3.91

The researcher refers the improvement of the experimental group in the IA: of the competition of the research to using the educational program by using Wheetly model for constructive learing where information was given as tasks and every student have to share and think with her colleagues in her group till reaching to solution for these tasks, theses results are accordant to the study of Deadrson and others (2011)(24) ،Abdel Hamid Elyakobi (2010) (8)، Nedham (2010) (23) ،Melody Mhomaed (2015) (19)

\section{So}

proposition

the second ascertained providing that "there are statistical differences between the averages of the pre and post scales with experimental groupin the 
technical performance level and the digital level and the IAL of High Jump competition by the back for the post scale" It is shown from the results of the tables $(25,26)$ that there are differences with statistical indication between the post scales of the control and experimental groups in the technical performance of the competition where

calculated value reached 10.67 which is more than (T) schedule value at abstract level $0.05=1.68$ with percentage $50.84 \%$ and the effect size value reached 1.69

The researcher refers the excellence of the experimental group on the control group in the technical performance level of the competition to the educational program by using Wheetly model which helped the students to learn through small cooperating groups helping them to develop the ability to think, discuss and argument, communications skills and taking the responsibility helping them to learn in an exciting environment

In this regard, Masri Abdel Hamid (2003) mentions that it is a necessity to give a chance to the teachers to liberate themselves from the traditional methods and shapes in teaching the lessons to enable the learners to be creative reflecting this on the educational organizations and making them as a creative centers by using the non traditional method (18:475) it is shown from the results of the tables $(25,26)$ that there are differences with statistical indication between the post scales in the control and experimental groups of the research in the digital level of the competition of the study where (T) calculated value reached 18.73 which is more than (T) schedule value at abstract level $0.05=1.68$ with percentage $113.95 \%$ and effect size value reached 2.71

The researcher ascribes the excellence of the experimental group on the control group in the digital level of the competition to the excellence of the experimental group in the technical performance level of the competition which return to the educational program by using Wheetly model having a positive effect on the digital level of the competition of the research.

\section{Assiut Journal For Sport Science Arts}


It is shown from the results of tables $(25,26)$ that there are differences with statistical indication between the two post scales of the control and experimental groups in the IAL of the competition where (T) calculated value reached 10.77 more than (T) schedule value at abstract level $0.05=1.68$ with percentage $147.19 \%$ and effect size value reached 2.59 .

The researcher ascribes the excellence of the experimental group on the control group in the IAL to using the educational program by Wheetly model making the role of the students a positive one in the educational process and making the cooperative in working together helping them to increase their motivation toward learning.

These results are accordant to the results of the studies of Beadroson and others (2001) (24) Beak Walkou Ritch (2001) (25), Francoise (2010) (22), Zombash and Riman (2002) (27), Nedham (2010) (23) Abdel Hamid Elyacobi (2010) (8), Melody (2015) (19).

So the validity of the third proposition is ascertained that "there are differences with statistical indication between the two averages of the post scales of the control and experimental groups in the technical performance level, the digital level and IAL of the High Jump Competition by the back method for the experimental group"

\section{Conclusions}

and

\section{recommendations:}

In light of the research and its propositions and in the limits of the research sample and depending on the statistical handlings the researcher concluded that:

1) The educational program by using the Wheetly model for constructive learning has positive effect in the technical performance level, the digital level and IAL of High Jump Competition by the back method

2) The educational program by using the followed method (explanation and presentation) has a positive effect in the technical performance level, the digital level, and the IAL of High Jump Competition by the back method

3) Increase of the educational program efficacy by using Wheetly model more than using the followed method (explanation and presentation) 
in the technical performance level, the digital level and IAL of High Jump Competition by the back method

\section{Recommendations:}

Through the conclusions the researcher recommends the following:

1) Using the educational program by applying Wheetly model for learning the High Jump Competition by the back method for the students of the second year of the faculty of physical education, Tanta University

2) Performing similar studies using Wheetly model for learning the physical activities generally and the field and racetrack competitions particularly.

3) Encouraging the staff and their assistants to use Wheetly model in learning the physical activities

\section{References :-}

Firstly / Arabic references : -

1- Osama Ahmed Adel : effect of educational program by using hypermedia for the beginners, unpublished master dissertation, faculty of physical education, El Menia university, 2001

2- Amin El Kholed and Gamal EL Shafie: methodologies of contemporary physical education, Dar El Fekr El Araby, Cairo „, 2001

3- Bastawisi Ahmed : races of racetrack and field- education technique- training, Dar El Fekr El Araby , Cairo, 1997

\section{4- Zakia Ibrahim Kamel:} teaching methods in physical education, technical radiation bookshop and printing house, Alexandria, 2002

\section{5- Saad El Din El Shernobi} Abdel Moneim Haridi : field and racetrack competitions. Technical Radiation Press and Bookshop. Alex.. 1998

\section{6- Shimaa Sadek Hamed:} suggested educational program by using very fast media (hypermedia) and its effect in the aspects of learning the long leap skill in the students of the second stage of the elementary education, unpublished master dissertation, faculty of physical education , Tanta, 2009

\section{7- Sedki Ahmed Salam:} athletics , competitions of field, leap and throwing and its related aspects, first edition Modern Book center ,Cairo 2014

8- Abdel Hamid EL Yakobi : technical program employing learning strategy centralized around the problem for developing the systematic 
thinking skills in science, for the students of the ninth grade in Ghaza, unpublished master dissertation, faculty of education, Islamic university, Ghaza 2010.

\section{9- Abdel Rahman Abdel} HamedZaher: mechanism of training and teaching athletics competitions, first edition, House center for publishing, Cairo, 2009

\section{0- Abdel Wahab El Sadek}

Mohamed: comparative study of the effect of billiometrictraning by using different means at the digital level in Libya, unpublished doctorate, faculty of physical education for boys, Alex university, 2012 11- Liyla El SayedFarahat : sports informational scale, first edition, Book center for publishing, Cairo 2001

12- Liyla El SayedFarahat: scale and testing in the physical education, fifth edition, Book center for publishing, Cairo, 2001

\section{3- Magdy Aziz Ibrahim:} strategies of education and learning methods, Egyptian Anglo bookshop, Cairo, 2004

14- Mohamed El Sayed Ali EL Kasabani: teaching models and applications in sciences, math, Arabic, and social studies, first edition, Dar El Fekr El Arabi, Cairo, 2008

\section{5- Mohamed SaadZaghlol,} Mohamed Ali Mahmoud Hani Said: design and product of educational computer program prepared by hypermedia and its effect on the aspects of learning skills of hitting the ball by the head for the students of the physical education faculty in Tanta, published research, theories magazine, No. (48), faculty of physical education for boys, Alex , 2002

\section{6- Mohamed Sobhi}

Hassanin: scale and evaluation in physical and sports education, sixth edition, Dar El Fekr El Arabi

\section{7- Mahmoud Mohamed} Eid: time analysis as a basis in dividing the minor training unit and its effect on the special physical factors and the digital level in the high leap by (Faloub method), unpublished master dissertation, faculty of physical education, Sadat university , 2015

18- Masri
Habdel Hamed
development $\begin{aligned} & \text { creation } \\ & \text { from integral }\end{aligned}$
perspective, third edition,
Egyptian Anglo Bookshop,
Cairo, 2003


19- Melody Mohamed Saad : effect of using Wheetly model for constructive learning supported by educational program on some hockey sport skills for the students of the physical education faculty in Tanta, unpublished master dissertation, faculty of physical education, Tanta University 2015

20- Yehia Abo Harb, Ali Ben Sharaf EL Mosi Ata Abo Habiba: the new in cooperative learning and high learning, El Falah Bookshop, Kuwait , 2004

\section{Second: Foreign References}

21- Deliel, $\mathbf{R}$ : How to use problem based learning in the classroom, Usa Ascd, 2001 .

22- Fransworth , $\mathbf{R}$ : The use Flexible, in teractive, situationfocused Software the Elearning of mathematics, Usa :triomal School , 2001

23- Needham, M.Elaine: Comparison of Stand-ar di zed Test Scorefromtraditional classroom sand those using problem based learning, proquest LLc, ph.D. Dissertation, university of Missoun Kansas city, 2010. 24- Pederson, S, Williams : The Design of " Alien Rescue " problem Based Learning Software for middle school scien The national convention of The association for education acomm Urirations and technology , Atlanta, 2001 25- Peek, Maloom Richie: Distance education on an interactive video network a study of teacher student in traction, Arizona state university, 2001 .

26- Knowles , M., : The Adult learner, Houston: Gulf publishing, 2001 .

27- Zumbach , J , Reimann : Influence of Feed buck on distributecd problem based learning: Designing for learning environments, Dordrecht : Kluwer, 2003. 